\title{
CONSTRUCTING AN INNOVATION ADOPTION CONCEPTUAL LENS/PRELIMINARY FRAME WORK FOR FURTHER TESTING IN UPSTREAM OIL AND GAS
}

\author{
Sylesh Nechully \\ Research Scholar, University of Petroleum and Energy Studies, Dehradun, India \\ Dr. S.K. Pokhriyal \\ Professor and Head - Energy Management, \\ School of Business - University of Petroleum and Energy Studies, Dehradun, India
}

\begin{abstract}
ABTRACT
Conceptual Lens helps to focus our study along certain directions for answering the research questions. A Conceptual Lens made from the existing literature helps the researcher to frame relevant questions to be asked to the respondents. In this paper, the researcher describes a method for constructing conceptual lens and employs the same method for constructing an innovation adoption conceptual lens for further testing in upstream oil and gas. The Conceptual lens can be treated as the starting point for qualitative data analysis.
\end{abstract}

Keywords: Conceptual Lens, Preliminary Frame Work, Qualitative Analysis, Coding, Variables, Upstream Oil and Gas.

Cite this Article: Sylesh Nechully and Dr. S.K. Pokhriyal, Constructing an Innovation Adoption Conceptual Lens/Preliminary Frame Work for Further Testing in Upstream Oil and Gas, International Journal of Advanced Research in Engineering and Technology, 10(2), 2019, pp.517-541.

http://iaeme.com/Home/issue/IJARET?Volume $=10 \&$ Issue $=2$

\section{INTRODUCTION}

Conceptual Lens helps to focus our study along certain directions for answering the research questions. A Conceptual Lens made from the existing literature helps the researcher to frame relevant questions to be asked to the respondents. A conceptual frame work helps the researcher to develop insights to the topic under study. Developing a conceptual frame work helps to strengthen the theoretical back ground of the researcher. A conceptual frame work saves time and effort of the researcher as it provides specific focus for study. A Conceptual lens is the starting point for qualitative data analysis. A conceptual frame work helps to reach a specific conclusion from a general premise - helps in deductive reasoning. Developing a conceptual lens helps to unravel the prospective variables influencing the process under study and tentative 
relationships between these variables - these variables and relationships will be further tested in the area of research (Anderson and Krathwohl, 2001).

\section{CONSTRUCTION METHOD}

The Researcher has followed the below furnished method for the construction of Conceptual Lens/Preliminary Frame work. The first step is to do the Literature Review of relevant concepts/theories/models related to the topic under study. Subsequently the Transcript of these theories and models are to be made. The researcher has to read the transcript several times to get himself thoroughly familiarized with the theories or concepts. The next step is to perform a content analysis of the prepared transcript. The process of coding starts with open coding. A table of emerging open codes are made. These open codes are also to be properly defined. The researcher needs to revisit the table many times. If needed, the researcher needs to go through the transcript again. Now the patterns of relationship among these codes will start emerging in the mind of researcher. The researcher has to go for axial coding where the open codes are grouped to various categories of codes. Axial codes are also properly defined. Selective coding helps to connect these categories to a core category or concept. Selective coding results in the creating of tentative conceptual lens or preliminary frame work. The transcript is again read for any missing concept/code or variable or relationship. The researcher finalizes the conceptual lens or preliminary frame work for further testing. Codes are also fine-tuned - which serves as pre-defined codes for further analysis.

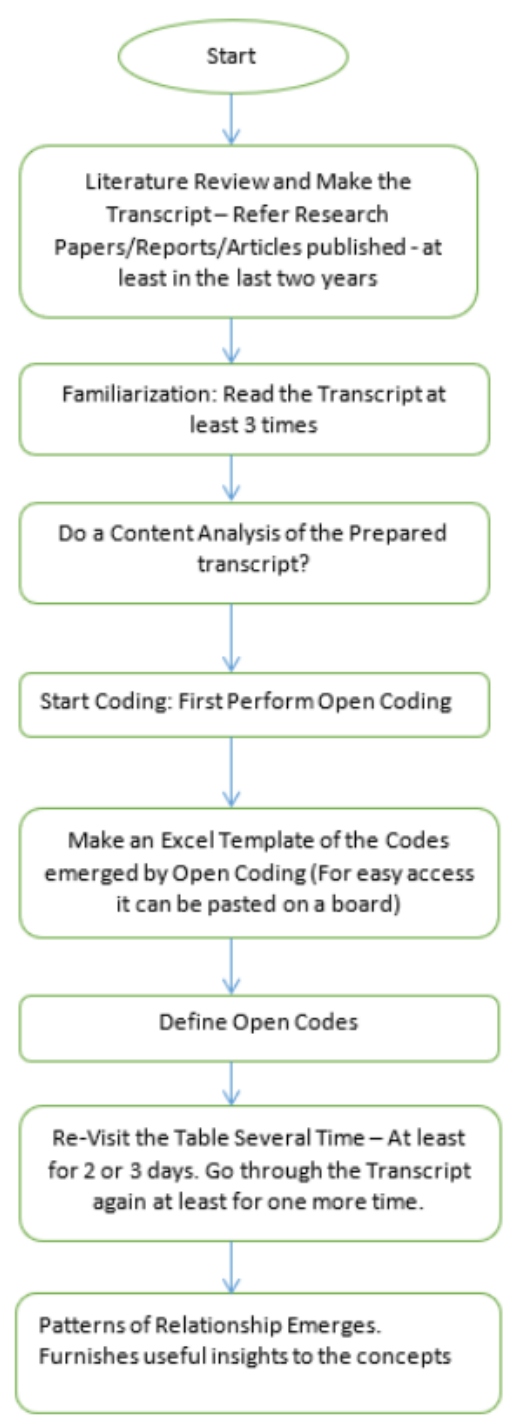




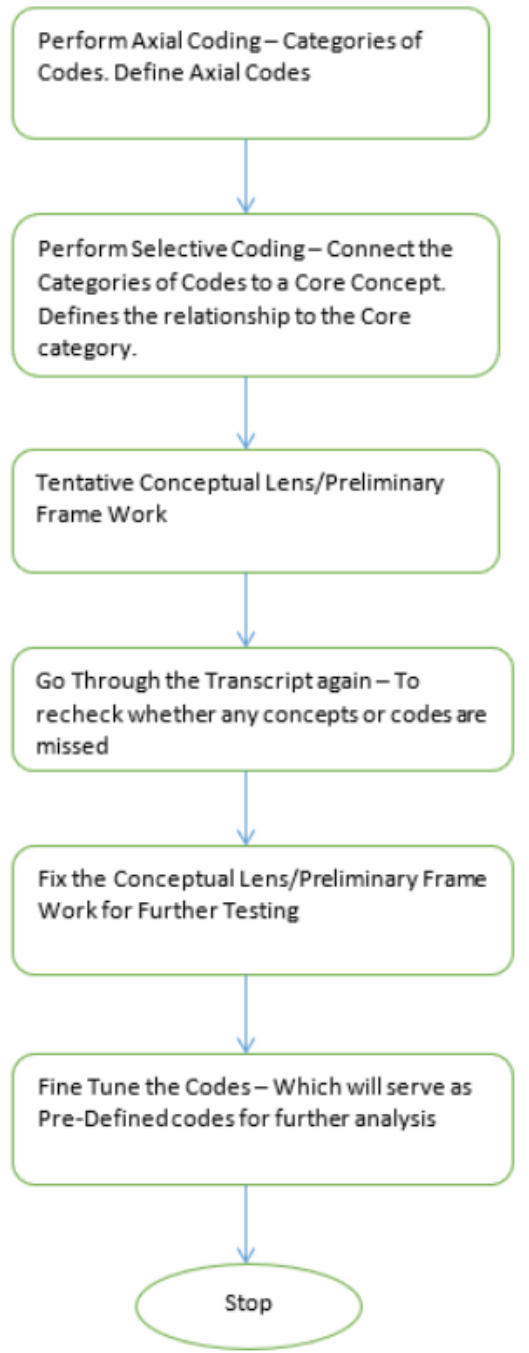

Figure 1 Conceptual Lens Construction Method

\section{CONCEPTUAL LENS CONSTRUCTION}

Construction of a Conceptual Lens starts with looking at process of adoption from an Organizational perspective. Organization should be always on the lookout for improvement opportunities. Organizations should encourage people to come up with betterment initiatives by appropriately rewarding them. This can be in the form of cash rewards/promotions/holidays or increments. The betterment opportunities can be either the introduction of a new process/routines or modification of the existing processes or it can be modification of an existing product or replacing the product with an innovation. Once the betterment opportunities are identified, the search for the solutions start. Anything new to the organization can be called as an innovation. So the organization decides to adopt a new product or service or technology to modify existing product or service or technology to exploit the innovation opportunity. This can be called as the First phase of adoption - Pre Adoption. The opportunities for improvement come from external parties as well. An innovator/channel can also suggest betterment opportunities. The pre-adoption phase ends with a decision to adopt an innovative product or technology.

The evaluation of alternatives is done at the pre-adoption stage. In most of the scenarios, the organizations zero down on a particular type of technology in the pre-adoption stage and the adoption stage starts with the selection of the vendor to provide the particular technology. 
However, in this case, the researcher sticks on to the concept of Pre-adoption stage ending with the decision to go ahead with a particular innovation which can meet the requirement of the organization. In case of sophisticated technologies, the companies will not finalize unless and until they see a functioning prototype or only after gauging the result of prototype usage.

The Adoption stage starts with the Negotiation and Contract finalization. The scope of work is defined and finalized. Diverse departments/individuals are involved in this process and innovation should be customized to comply with the norms/procedures/systems of the organization. During the implementation stage, the organization has to enlist the support of all the relevant parties involved. Competent employees with the right attitude is the biggest asset an organization can have. For an organization to reap the benefits of an innovation, it is not only enough that the innovation is smoothly implemented, but the employees should use the innovation for what the innovation is meant to be. Employees have to use the innovation to solve their problems. Here comes the relevance of combining the both perspectives of innovation - Organizational and Individual. So the adoption process ends with the Employees utilizing the innovation with right skill set and attitude to achieve the objectives of the organization.

The utilization of innovation should yield favorable results to the organization. Favorable results lead to satisfaction and continued usage of innovation. If the innovation cannot yield favorable or desired results, organization abandons innovation and initiates the adoption process by scanning the market for appropriate innovation. Innovation adoption process is a continuous cycle. It has to be. Otherwise organizations cannot survive and prosper. At times, what happens is that, a superior innovation or governments regulations necessitates the replacement of innovations.

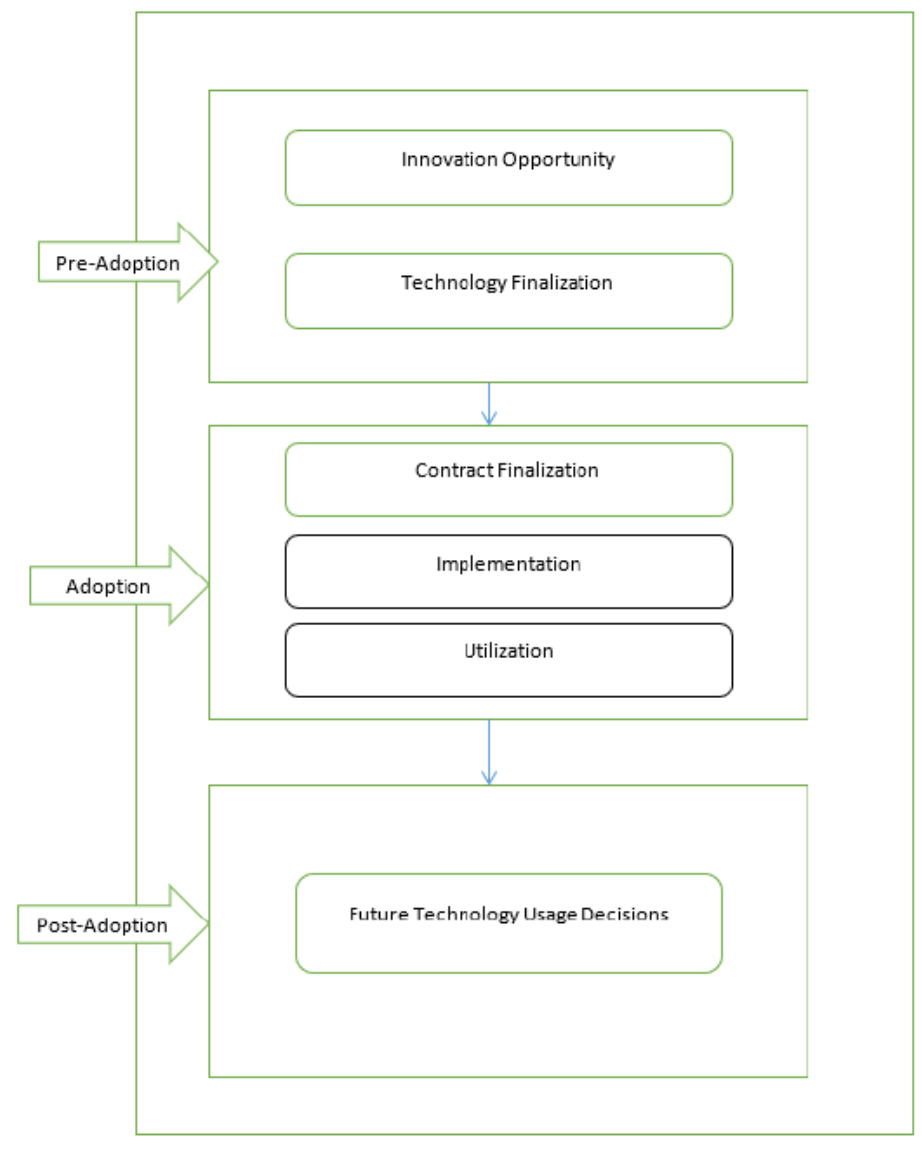

Figure 2 Various Stages Involved in the Adoption Process 
The Pre-adoption stage ends with Innovative Technology/Service Finalization. Adoption stage starts with Contract Finalization and end with Utilization of Innovation. Post adoption starts with the Future Usage of Technology/Service

Cooper and Zmud (1990) posit that the process stream of research should be combined with factor stream of research to get a holistic perspective of adoption. So to construct the conceptual lens, the researcher needs to fit the relevant variables to various stages of adoption. In general, most of the studies concentrate only on the Implementation stage of adoption. Some studies focus on Post adoption as well, but Pre-Adoption stages are often discarded. In this study, the researcher will be identifying the variables affecting the Pre-Adoption stage also along with Adoption and Post Adoption. Aforementioned method is followed for the construction of conceptual lens.

The Researcher has already done the literature review and published three papers (1) A Journey through the evolution of theories and models of adoption of innovations (Years: 1798 - 1980) (2) A Journey through the evolution of theories and models of adoption of innovations (Years: 1981 - 1999) (3) A Journey through the evolution of theories and models of adoption of innovations (Years: 2000 - 2018). So the researcher considers these three papers as the transcripts of theories and models of adoption and proceeds with the Content Analysis.

The conceptual lens or the preliminary frame work and the codes are tentatively drafted or defined. In the due course of qualitative data analysis, the frame work or codes may get modified and in some extreme cases may change completely. Academically "Correct" concepts can be or will be considered as "Wrong" due to its practical implications/difficulties. Similarly, some of the variables used in Academic and Industry contexts may be different. So the variables have to be given an "Industry/Sector" specific explanation.

\subsection{OPEN CODING}

The coding process starts with open coding. The emerging open codes are tabulated. Identical or Similar codes are removed from or merged in the table (Strauss and Corbin, 1990).

\begin{tabular}{|c|c|c|}
\hline S No & Variables/Factors & Author(s) \\
\hline 1 & $\begin{array}{l}\text { Geographical } \\
\text { Proximity }\end{array}$ & Ratzel (1882), Frobenius (1898), Schmidt (1906), Graebner (1909) \\
\hline 2 & Local Adaptations & Ratzel (1882), Frobenius (1898), Schmidt (1906), Graebner (1909) \\
\hline 3 & Imitation & $\begin{array}{l}\text { Wissler (1923), Kroebner (1940), Tarde (1886), Dixon (1928), Bass } \\
\text { (1969), Bandura (1961), Bass (1969), Lindzey and Aronsson (1985), } \\
\text { Turner and Killan (1987), Haunschild and Miner (1997), Teng, Grover } \\
\text { and Gutter (2002), Aguiar and Reis (2008) }\end{array}$ \\
\hline 4 & Number of Adopters & Malthus (1798), Granovetter, 1978) \\
\hline 5 & Resources & Pearl (1920), Nowak (1992), Statnikova (2005) \\
\hline 6 & Competition & $\begin{array}{c}\text { Pearl (1920), Maidique and Zirger (1985), Kaun and Chau (2001), } \\
\text { Slappendel (1996), Dasgupta, Agarwal and Gopalakrishnan (1999), } \\
\text { Frambach and Schillewaert (2002), Modis (2003) }\end{array}$ \\
\hline 7 & $\begin{array}{l}\text { Organizational } \\
\text { Readiness }\end{array}$ & Tylor (1922), Lacovou (1995) \\
\hline 8 & Demonstration & $\begin{array}{c}\text { Dixon (1928), Karahanna, Chervany and Straub (1999), Venkatesh and } \\
\text { Davis (2000), Pignatti, Carli and Canavari (2015) }\end{array}$ \\
\hline 9 & Fashion & Dixon (1928), Abramson (1991) \\
\hline 10 & Organizational Culture & $\begin{array}{l}\text { Dixon (1928), Linton (1936), Kluckhohn and Strodtbeck (1961), Hauser } \\
\text { and Wisniewski (1982), Dasgupta, Agarwal and Gopalakrishnan (1999) }\end{array}$ \\
\hline 11 & Conformity & Dixon (1928) \\
\hline
\end{tabular}


Constructing an Innovation Adoption Conceptual Lens/Preliminary Frame Work for Further Testing in Upstream Oil and Gas

\begin{tabular}{|c|c|c|}
\hline S No & Variables/Factors & Author(s) \\
\hline 12 & Inertia & $\begin{array}{l}\text { Dixon (1928), Linton (1936), Kluckhohn and Strodtbeck (1961), Hauser } \\
\text { and Wisniewski (1982), Statnikova (2005), }\end{array}$ \\
\hline 13 & $\begin{array}{l}\text { Organizational } \\
\text { Customs }\end{array}$ & Dixon (1928) \\
\hline 14 & Personality & Dixon (1928) \\
\hline 15 & Feedback & Dixon (1928), Homer (1987), Burkman (1987) \\
\hline 16 & Information & $\begin{array}{c}\text { Pyzalska (2018), Guseo and Mortarino (2015), Nkegbe and Shankar } \\
\text { (2014), Pierpaolia, Carli and Pinattia (2013), Arnholt and Balte (2003), } \\
\text { Gaudet (1930), Linton (1936), Wilkening (1953), Yapa and Mayfield } \\
\text { (1978), Dodson and Muller (1978), Wilson (1981), Deng (1982), Daft } \\
\text { and Lengel (1986), Roling (1988), Bhargava, Kumar and Mukherjee } \\
\text { (1993), Strang and Soule (1998), Gladwell (2000) }\end{array}$ \\
\hline 17 & Economic Benefits & $\begin{array}{c}\text { Aizstruata, Ginters and Eroles (2015), Pierpaolia, Carli and Pinattia } \\
\text { (2013), Hudson and Hite (2003), Linton (1936), Griliches (1957), } \\
\text { Bandura (1961), Blackman (1971), Anderson (1971), Ogunlade (1979), } \\
\text { Tani (1988), Ellis (1989), Lilen (1990), Tornatzky and Fleischer (1990), } \\
\text { Besley and Case (1995), Nowak (1992), Karshenas and Stoneman } \\
\text { (1993), Keller (1996), Gelb and Voet (2009) }\end{array}$ \\
\hline 18 & Available Knowledge & Linton (1936), \\
\hline 19 & Receptivity & Linton (1936), \\
\hline 20 & Aftersales Service & $\begin{array}{c}\text { Samuelson (1938), Tanner (1974), Lieberman and Paroush (1982), } \\
\text { Bayus (1992), Hardie, Fader and Wisneiwski (1998), Ruyters, Wetzel } \\
\text { and Kleijnen (2001) }\end{array}$ \\
\hline 21 & Price & $\begin{array}{l}\text { Gillespie, Kim and Pandel (2007), Samuelson (1938), Wilkening (1953), } \\
\text { Bass (1969), Grubler (1991), Kotler (1971), Tanner (1974), Jeuland and } \\
\text { Dolan (1981), Lieberman and Paroush (1982), Thomas and Teng (1983), } \\
\text { Feichtinger (1985), Kamakura and Balasubramaniam (1988), Biddle } \\
\text { (1991), Schmidt and Porteus (2000), Venkatesh and Morris (2003), } \\
\text { Paudel, Mishra and Segarra (2011), Pierpaolia, Carli and Pinattia (2013) }\end{array}$ \\
\hline 22 & Purchasing Patterns & Samuelson (1938) \\
\hline 23 & Company Size & $\begin{array}{c}\text { Schumpeter (1942), Arrow (1962), Tani (1988), Henderson and Clark } \\
\text { (1990), Slappendel (1996), Libertore and Bream (1997), Majumdar and } \\
\text { Venkataraman (1998), Dasgupta, Agarwal and Gopalakrishnan (1999), } \\
\text { Frambach and Schillewaert (2002) }\end{array}$ \\
\hline 24 & Market Structure & $\begin{array}{c}\text { Schumpeter (1942), Arrow (1962), Tani (1988), Henderson and Clark } \\
\text { (1990), Slappendel (1996), Libertore and Bream (1997), Majumdar and } \\
\text { Venkataraman (1998), Dasgupta, Agarwal and Gopalakrishnan (1999), } \\
\text { Gruber and Verboven (2000) }\end{array}$ \\
\hline 25 & Personal Network & Ryan and Gross (1940) \\
\hline 26 & $\begin{array}{c}\text { Mass } \\
\text { Communication/Media }\end{array}$ & $\begin{array}{c}\text { Ryan and Gross (1940), Coleman (1966), Mcquail and Blumer (1969), } \\
\text { Rokeach and Defleur (1976), }\end{array}$ \\
\hline 27 & Opinion Leaders & Lazarfeld (1944), Ngambi and Bozalek (2013) \\
\hline 28 & Reference Group & Duessenberry (1949), Joshi and Sharma (2004) \\
\hline 29 & Leadership & $\begin{array}{c}\text { Wilkening (1953), Weber (1968), Norris and Soloway (2011), Ngambi } \\
\text { and Bozalek (2013), Randall and Coakley (2007) }\end{array}$ \\
\hline 31 & Seasonality & Wilkening (1953), Radas and Shugan (1998), Strang and Macy (2001) \\
\hline 33 & User Experience & Wilkening (1953) \\
\hline 35 & User Skills & $\begin{array}{l}\text { Wilkening (1953), Coale (1973), Feder, Just and Zilberman (1982), } \\
\text { Scherer (1986), Gustafson (1986), Francik (1991), Greenwood and }\end{array}$ \\
\hline
\end{tabular}




\begin{tabular}{|c|c|c|}
\hline S No & Variables/Factors & Author(s) \\
\hline & & $\begin{array}{l}\text { Yorokolgu (1997), Kennickell and Kwast (1997), Reichardt and Jurgens } \\
\qquad(2009)\end{array}$ \\
\hline 37 & Risk & $\begin{array}{c}\text { Pavlou (2003), Wilkening (1953), Feder, Just and Zilberman (1982), } \\
\text { Chatterjee and Eliashberg (1990), Arthur, Durlauf and Lane (1997), } \\
\text { Eastlick and Lotz (1999), Ruyters, Wetzel and Kleijnen (2001), } \\
\text { Diederen, Meijl and Wolters (2003) }\end{array}$ \\
\hline 39 & $\begin{array}{l}\text { Satisfaction with Old } \\
\text { Practices }\end{array}$ & Wilkening (1953), Norris and Soloway (2011) \\
\hline 41 & Objectives & Wilkening (1953) \\
\hline 43 & Network Membership & $\begin{array}{l}\text { Wilkening (1953), Neiman (1966), Drazen and Rao (1996), Frambach } \\
\text { and Schillewaert (2002) }\end{array}$ \\
\hline 45 & Alternatives & Greena and Mayo (1954), Botha and Atkins (2005 \\
\hline 47 & Expectations & $\begin{array}{l}\text { Festinger (1957), Robertson (1971), Vessey (1991), Taylor and Todd } \\
\text { (1995), Goldenberg, Libai and Solomon (2000), Sun, Neslin and } \\
\text { Srinivasan (2003) }\end{array}$ \\
\hline 49 & $\mathrm{R} \& \mathrm{D}$ & Griliches (1957), Arnholt and Balte (2003) \\
\hline 51 & Market Potential & $\begin{array}{c}\text { Griliches (1957), Bass (1969), Norton and Bass (1987), Jain and Roa } \\
\text { (1990), Horsky (1990) }\end{array}$ \\
\hline 52 & Innovativeness & Watenabe (2006), Christia (2000), Porter and Donthu (2006) \\
\hline 53 & Attitude & $\begin{array}{l}\text { Turner and Killian (1957), Anderson (1971), Fishbein and Ajzen (1975), } \\
\text { Yapa and Mayfield (1978), Thompson, Higgins and Howell (1991), } \\
\text { Taylor and Todd (1995), Eastlick and Lotz (1999), Frambach and } \\
\text { Schillewaert (2002), Statnikova (2005), Wang and Liu (2009), Tohidyan } \\
\text { and Moghaddam (2015) }\end{array}$ \\
\hline 54 & Norms & Turner and Killian (1957) \\
\hline 55 & Investment & Mansfield (1961) \\
\hline 56 & Ease of Use & $\begin{array}{l}\text { Rogers (1962), Hauser and Wisniewski (1982), Davis, Bagozzi and } \\
\text { Warshaw (1989), Tornatzky and Fleischer (1990), Goodhue and } \\
\text { Thomson (1995), Karahanna, Chervany and Straub (1999), Malhotra and } \\
\text { Galletta (1999), Venkatesh and Morris (2003), Pavlou (2003), Assael } \\
\text { (1998), Carter and Weerakkody (2008), Collan (2007), Gelb and Voet } \\
\text { (2009), Casalo, Flavian and Guinaliv (2012), Porter and Donthu (2006), } \\
\text { Tohidyan and Moghaddam (2015), Pignatti, Carli and Canavari (2015), } \\
\text { Boonsiritomachai and Pitchayadejanant (2017) }\end{array}$ \\
\hline 57 & Ease to learn & Rogers (1962) \\
\hline 58 & Word of mouth & $\begin{array}{c}\text { Rogers (1962), Dodson and Muller (1978), Hauser and Wisniewski } \\
\text { (1982), Mahajan, Muller and Kerin (1984), Thomas and Teng (1983), } \\
\text { Kalish (1985), Harvey (2009) }\end{array}$ \\
\hline 59 & $\begin{array}{l}\text { Availability for Hands } \\
\text { on }\end{array}$ & $\begin{array}{l}\text { Rogers (1962), Kelly and Kranzberg (1978), Yapa and Mayfield (1978), } \\
\text { Hauser and Wisniewski (1982), Karahanna, Chervany and Straub (1999) }\end{array}$ \\
\hline 60 & Fit to Work Settings & Rogers (1962), Thompson, Higgins and Howell (1991) \\
\hline 61 & Facilitating Conditions & $\begin{array}{c}\text { Smelser (1963), Thompson, Higgins and Howell (1991), Taylor and } \\
\text { Todd (1995), Venkatesh and Morris (2003), Statnikova (2005), } \\
\text { Boonsiritomachai and Pitchayadejanant (2017),Mengesha and Garfiels } \\
\text { (2018) }\end{array}$ \\
\hline 62 & Quality & $\begin{array}{c}\text { Vernon (1966), Lilen (1990), Delone and Mclean (1992), Venkatesh and } \\
\text { Davis (2000) }\end{array}$ \\
\hline 63 & Economies of Scale & Vernon (1966), Tani (1988), Shepard and Saloner (1995) \\
\hline 64 & Last ditch effort & Ward (1967) \\
\hline
\end{tabular}


Constructing an Innovation Adoption Conceptual Lens/Preliminary Frame Work for Further Testing in Upstream Oil and Gas

\begin{tabular}{|c|c|c|}
\hline S No & Variables/Factors & Author(s) \\
\hline 65 & Timing & Hagerstrand (1967), Lehman and Weinberg (2000) \\
\hline 66 & Channel & Hagerstrand (1967), Roling (1988), Ritz and Morgan (1991) \\
\hline 67 & Product Features & $\begin{array}{l}\text { Floyd (1968), Hughes (1983), Roberts and Urban (1988), Narasimhan, } \\
\text { Sen and Neslin (1996), Marez (2006), Gelb and Voet (2009) }\end{array}$ \\
\hline 68 & Performance & $\begin{array}{l}\text { Grubler (1991), Tolbert and Zucker (1983), Francik (1991), Wang and Li } \\
\text { (2010), Boonsiritomachai and Pitchayadejanant (2017) }\end{array}$ \\
\hline 69 & Advertisement & $\begin{array}{l}\text { Casetti (1969), Dodson and Muller (1978), Horsky and Simon (1983), } \\
\text { Thomas and Teng (1983), Maidique and Zirger (1985), Kalish (1985), } \\
\text { Simon and Sebastian (1987), Narasimhan, Sen and Neslin (1996) }\end{array}$ \\
\hline 70 & Substitution & Fischer and Pry (1971), Srivastava and Leone (1981) \\
\hline 71 & Market Share & Fischer and Pry (1971) \\
\hline 72 & Legitimization & Robertson (1971), Tolbert and Zucker (1983), Wang and Li (2010) \\
\hline 73 & $\begin{array}{l}\text { Organizational } \\
\text { Innovativeness }\end{array}$ & $\begin{array}{c}\text { Kotler (1971), Feder, Horsky and Simon (1983), Frambach and } \\
\text { Schillewaert (2002) }\end{array}$ \\
\hline 74 & $\begin{array}{c}\text { Individual } \\
\text { Innovativeness }\end{array}$ & $\begin{array}{l}\text { Kotler (1971), Frambach and Schillewaert (2002), Tohidyan and } \\
\text { Moghaddam (2015) }\end{array}$ \\
\hline 75 & Scientific Credibility & Kotler (1971) \\
\hline 76 & Relative Advantage & $\begin{array}{c}\text { Kotler (1971), Kelly and Kranzberg (1978), Arthur (1994), Taylor and } \\
\text { Todd (1995), Ruyters, Wetzel and Kleijnen (2001) }\end{array}$ \\
\hline 77 & Personal Influences & Kotler (1971), Scherer (1986) \\
\hline 78 & $\begin{array}{c}\text { Social } \\
\text { Approval/Influence }\end{array}$ & $\begin{array}{c}\text { Kotler (1971), Venkatesh and Morris (2003), Talukder, Harris and } \\
\text { Mapunda (2012) }\end{array}$ \\
\hline 79 & Willingness & Coale (1973), Hudson and Hite (2003) \\
\hline 80 & Absorptive Capacity & Coale (1973), Levinthal (1990), Keller (1996) \\
\hline 81 & Reversibility & Zaltman (1973), Kelly and Kranzberg (1978) \\
\hline 82 & $\begin{array}{l}\text { Realization (Duration } \\
\text { for Result) }\end{array}$ & Zaltman (1973) \\
\hline 83 & Customization & Zaltman (1973), Ram (1987) \\
\hline 84 & Subjective Norms & $\begin{array}{c}\text { Fishbein and Ajzen (1975), Tirandis (1977), Taylor and Todd (1995), } \\
\text { Venkatesh and Davis (2000) }\end{array}$ \\
\hline 85 & Motivation & $\begin{array}{c}\text { Fishbein and Ajzen (1975), Tirandis (1977), Davis, Bagozzi and } \\
\text { Warshaw (1992) }\end{array}$ \\
\hline 86 & Beliefs of outcome & $\begin{array}{l}\text { Fishbein and Ajzen (1975), Tirandis (1977), Oliver (1980), Parasuraman } \\
(2000)\end{array}$ \\
\hline 87 & Evaluation of outcome & Fishbein and Ajzen (1975), Tirandis (1977), Oliver (1980) \\
\hline 88 & Normative beliefs & Fishbein and Ajzen (1975), Tirandis (1977) \\
\hline 89 & $\begin{array}{l}\text { Technological } \\
\text { advances }\end{array}$ & Hernes (1976), Gruber and Verboven (2000) \\
\hline 90 & Roles & Triandis (1977), Levinthal (1990), Francik (1991) \\
\hline 91 & $\begin{array}{l}\text { Frequency of Past } \\
\text { Behavior }\end{array}$ & Triandis (1977) \\
\hline 92 & Habit & Triandis (1977), Davis, Venkatesh and Morris (2003), \\
\hline 93 & Compatibility & $\begin{array}{l}\text { Kelly and Krantzberg (1978), Taylor and Todd (1995), Goodhue and } \\
\text { Thomson (1995), Carter and Weerakkody (2008), Megesha and Garfield } \\
\text { (2018) }\end{array}$ \\
\hline 94 & Standards & $\begin{array}{c}\text { Midgley and Dowling (1978), Ogunlade (1979), Kaniovski, Arthur and } \\
\text { Ermoleiv (1987), Chau and Tam (1997), Harvey (2009) }\end{array}$ \\
\hline
\end{tabular}




\begin{tabular}{|c|c|c|}
\hline S No & Variables/Factors & Author(s) \\
\hline 95 & Statutory Compliance & Midgley and Dowling (1978), Lilien (1980), Slappendel (1996) \\
\hline 96 & Social Media & Rangaswamy and Gupta (2000) \\
\hline 97 & Re-Purchase & Dodson and Muller (1978) \\
\hline 98 & Technology Steward & $\begin{array}{c}\text { Ogunlade (1979), Gustafson (1986), Joshi and Sharma (2004), Wenger, } \\
\text { White and Smith (2009), Perez, Popadiuk and Cesar (2017) }\end{array}$ \\
\hline 99 & Marketing Strategies & $\begin{array}{c}\text { Mahajan and Peterson (1980), Lieberman and Paroush (1982), Frambach } \\
\text { and Schillewaert (2002) }\end{array}$ \\
\hline 100 & Re-Invention & Rice (1980), Kaipa, 2012 \\
\hline 101 & $\begin{array}{l}\text { History of Past } \\
\text { purchases }\end{array}$ & $\begin{array}{l}\text { Hauser and Wisniewski (1982), Scherer (1986), Venkatesh and Davis } \\
(2000)\end{array}$ \\
\hline 102 & Safety & Hauser and Wisniewski (1982) \\
\hline 103 & Opinions & Hauser and Wisniewski (1982) \\
\hline 104 & Convenience & Hauser and Wisniewski (1982) \\
\hline 105 & Direct Email & Hauser and Wisniewski (1982) \\
\hline 106 & Publicity & Hauser and Wisniewski (1982) \\
\hline 107 & Budget allocation & Hauser and Wisniewski (1982) \\
\hline 108 & Preference & Hauser and Wisniewski (1982), Scherer (1986) \\
\hline 109 & Credit Availability & Feder, Just and Zilberman (1982), Besley and Case (1995) \\
\hline 110 & Isomorphism & Dimaggio and Powell (1983) \\
\hline 111 & Hype Cycles & Minsky (1986) \\
\hline 112 & Exciting Benefits & Kano (1984) \\
\hline 113 & Fear of Change & Sharif and Ramanathan (1984) \\
\hline 114 & Market conditions & Hannan and Mcdowell (1984), Yates (1989) \\
\hline 115 & Prevailing Wage Rates & Hannan and Mcdowell (1984), Tani (1988) \\
\hline 116 & High Education Levels & $\begin{array}{l}\text { Pignatti, Carli and Canavari (2015), Hudson and Hite (2003), Hannan } \\
\text { and Mcdowell (1984), Kwon and Zmud (1987), Kennickell and Kwast } \\
\text { (1997), Caselli and Coleman (2001), Gelb and Voet (2009), Paudel, } \\
\text { Mishra and Segarra (2011), Pierpaolia, Carli and Pinattia (2013) }\end{array}$ \\
\hline 117 & Management Support & $\begin{array}{c}\text { Maidique and Zirger (1985), Teo (2008), Igbaria, Parasuraman and } \\
\text { Baroudi (1996), Statnikova (2005) }\end{array}$ \\
\hline 118 & Cross functional teams & Maidique and Zirger (1985) \\
\hline 119 & Network Externality & $\begin{array}{c}\text { Farrel and Saloner (1985), Besley and Case (1995), Dekimpe, Parker and } \\
\text { Sarvary (2000), Frambach and Schillewaert (2002) }\end{array}$ \\
\hline 120 & ROI & Feichtinger (1985), Pignatti, Carli and Canavari (2015) \\
\hline 121 & $\begin{array}{l}\text { Perceived Behavioral } \\
\text { Control }\end{array}$ & Ajzen (1985), Taylor and Todd (1995) \\
\hline 122 & $\begin{array}{l}\text { History of Past } \\
\text { purchases }\end{array}$ & $\begin{array}{l}\text { Boyd and Richerson (1985), Ellison and Drew (1991), Mahler and Roger } \\
\text { (1999) }\end{array}$ \\
\hline 123 & Innovator Support & Gustafson (1986) \\
\hline 124 & $\begin{array}{c}\text { Continuous monitoring } \\
\text { of Output }\end{array}$ & Gustafson (1986) \\
\hline 125 & Innovation policy & Ergas (1987), Yates (1989), Parmentola, Simoni and Tutore (2015) \\
\hline 126 & Resistance to change & $\begin{array}{l}\text { Kwon and Zmud (1987), Ram (1987), Levinthal (1990), Norris and } \\
\text { Soloway (2011) }\end{array}$ \\
\hline 127 & Job Tenure & Kwon and Zmud (1987) \\
\hline 128 & Job Roles & Kwon and Zmud (1987) \\
\hline
\end{tabular}

http://iaeme.com/Home/journal/IJARET 525 editor@iaeme.com


Constructing an Innovation Adoption Conceptual Lens/Preliminary Frame Work for Further Testing in Upstream Oil and Gas

\begin{tabular}{|c|c|c|}
\hline S No & Variables/Factors & Author(s) \\
\hline 129 & $\begin{array}{l}\text { Inter-organizational } \\
\text { Dependence }\end{array}$ & Kwon and Zmud (1987) \\
\hline 130 & Uncertainty & Kwon and Zmud (1987), Dixit and Pindyck (1994) \\
\hline 131 & Organization Structure & Homer (1987), Levinthal (1990), Frambach and Schillewaert (2002) \\
\hline 132 & $\begin{array}{l}\text { Organizational } \\
\text { Strategies }\end{array}$ & Homer (1987) \\
\hline 133 & $\begin{array}{l}\text { Perceived Innovation } \\
\text { Characteristics }\end{array}$ & $\begin{array}{l}\text { Ram (1987), Karahanna, Chervany and Straub (1999), Eastlick and Lotz } \\
\text { (1999), Frambach and Schillewaert (2002) }\end{array}$ \\
\hline 134 & $\begin{array}{c}\text { Consumer } \\
\text { Characteristics }\end{array}$ & $\operatorname{Ram}(1987)$ \\
\hline 135 & Media Characteristics & $\operatorname{Ram}(1987)$ \\
\hline 136 & Aftersales Service & Burkman (1987), Tornatzky and Fleischer (1990) \\
\hline 137 & Brand Loyalty & Burkman (1987), Assael (1998), Harvey (2009) \\
\hline 138 & Prototype & Burkman (1987) \\
\hline 139 & Contingent Innovation & Bayus (1987), Gates (1998) \\
\hline 140 & $\begin{array}{c}\text { Intergenerational } \\
\text { Competitions }\end{array}$ & Norton and Bass (1987), Kim, Chang and Shocker (1998) \\
\hline 141 & Habit & Norton and Bass (1987) \\
\hline 142 & $\begin{array}{l}\text { Organizational } \\
\text { Priorities }\end{array}$ & Yates (1989) \\
\hline 143 & Perceived Usefulness & $\begin{array}{l}\text { Davis, Bagozzi and Warshaw (1989), Arthur, Durlauf and Lane (1997), } \\
\text { Lacovou (1995), Igbaria, Parasuraman and Baroudi (1996), Karahanna, } \\
\text { Chervany and Straub (1999), Malhotra and Galletta (1999), Davis, } \\
\text { Venkatesh and Morris (2003), Pavlou (2003), Tung and Rieck (2005), } \\
\text { Talukder, Harris and Mapunda (2012), Casalo, Flavian and Guinaliv } \\
\text { (2012), Porter and Donthu (2006), Tohidyan and Moghaddam (2015) }\end{array}$ \\
\hline 144 & Purchasing Power & Lilen (1990), Horsky (1990) \\
\hline 145 & Working Environment & Tornatzky and Fleischer (1990), Keller (1996) \\
\hline 146 & Reputation of the Firm & $\begin{array}{c}\text { Tornatzky and Fleischer (1990), Keller (1996), Christia (2000), } \\
\text { Venkatesh and Davis (2000), Ruyters, Wetzel and Kleijnen (2001), Gelb } \\
\text { and Voet (2009) }\end{array}$ \\
\hline 147 & CEO Innovativeness & Thong (1999) \\
\hline 148 & $\begin{array}{c}\text { Knowledge of } \\
\text { Technology }\end{array}$ & Thong (1999) \\
\hline 149 & $\begin{array}{l}\text { Government } \\
\text { Regulation }\end{array}$ & Kaun and Chau (2001), Baker (2001), Cutler and Mcclellan (1996) \\
\hline 150 & Utility & Horsky (1990) \\
\hline 151 & Reduced Time & Horsky (1990) \\
\hline 152 & Routines & Levinthal (1990) \\
\hline 153 & $\begin{array}{l}\text { Complimentary } \\
\text { Infrastructure }\end{array}$ & $\begin{array}{l}\text { David (1990), Gruber and Verboven (2001), Wareham, Levy and Shi } \\
\text { (2004), Norris and Soloway (2011) }\end{array}$ \\
\hline 154 & $\begin{array}{c}\text { Long term } \\
\text { consequences }\end{array}$ & Thompson, Higgins and Howell (1991) \\
\hline 155 & Complexity & $\begin{array}{l}\text { Thompson, Higgins and Howell (1991), Nowak (1992), Statnikova } \\
\text { (2005) }\end{array}$ \\
\hline 156 & Training & $\begin{array}{c}\text { Francik (1991), Goodhue and Thomson (1995), Gelb and Voet (2009), } \\
\text { Pignatti, Carli and Canavari (2015), }\end{array}$ \\
\hline
\end{tabular}




\begin{tabular}{|c|c|c|}
\hline S No & Variables/Factors & Author(s) \\
\hline 157 & $\begin{array}{c}\text { Communication } \\
\text { Channels }\end{array}$ & Francik (1991), Perez, Popadiuk and Cesar (2017) \\
\hline 158 & Cost of adoption & Besley and Case (1995) \\
\hline 159 & User Satisfaction & Delone and Mclean (1992) \\
\hline 160 & Intention to use & Delone and Mclean (1992), Taylor and Todd (1995) \\
\hline 161 & Government Support & Kumar and Kumar (1992) \\
\hline 162 & Managerial Skills & Nowak (1992) \\
\hline 162 & Pleasurable Experience & Davis, Bagozzi and Warshaw (1992) \\
\hline 163 & Better Pay & Davis, Bagozzi and Warshaw (1992) \\
\hline 164 & $\begin{array}{l}\text { Enhanced Job } \\
\text { Performance }\end{array}$ & Davis, Bagozzi and Warshaw (1992) \\
\hline 165 & Herd Behavior & Banerjee (1992) \\
\hline 166 & Self-Efficacy & $\begin{array}{c}\text { Compeau and Higgins (1995), Taylor and Todd (1995), } \\
\text { Boonsiritomachai and Pitchayadejanant (2017) }\end{array}$ \\
\hline 167 & Management Myopia & Bower and Christensen (1995) \\
\hline 168 & $\begin{array}{l}\text { Organizational } \\
\text { Readiness }\end{array}$ & Lacovou (1995) \\
\hline 169 & Trading Partner Power & Lacovou (1995) \\
\hline 170 & Compliances & Scott and Christensen (1995), Karahanna, Chervany and Straub (1999) \\
\hline 171 & Market Share & Helper (1995) \\
\hline 172 & Relationship & $\begin{array}{l}\text { Helper (1995), Goodhue and Thomson (1995), Hubbard (1998), } \\
\text { Pyzalska (2018) }\end{array}$ \\
\hline 173 & Authority & Goodhue and Thomson (1995) \\
\hline 174 & Production Timeliness & Goodhue and Thomson (1995) \\
\hline 175 & System Reliability & Goodhue and Thomson (1995) \\
\hline 176 & Social Pressure & $\begin{array}{l}\text { Perez, Popadiuk and Cesar (2017), Igbaria, Parasuraman and Baroudi } \\
\text { (1996), Tung and Rieck (2005) }\end{array}$ \\
\hline 177 & Perceived Fun & Igbaria, Parasuraman and Baroudi (1996) \\
\hline 178 & Re-Invention & Hays (1996) \\
\hline 179 & Affordability & Golder and Tellis (1998), Norris and Soloway (2011) \\
\hline 180 & Income & $\begin{array}{c}\text { Kohli, Lehman and Pae (1999), Diederen, Meijl and Wolters (2003), } \\
\text { Watcharaanantapong, Lambert and Roberts (2014) }\end{array}$ \\
\hline 181 & Re-Organizing & Brynjolfsson and Hitt (1999) \\
\hline 182 & Image enhancement & Karahanna, Chervany and Straub (1999) \\
\hline 183 & Visibility & Karahanna, Chervany and Straub (1999) \\
\hline 184 & $\begin{array}{l}\text { Central Decision } \\
\text { Maker }\end{array}$ & Dekimpe, Parker and Sarvary (2000) \\
\hline 185 & Voluntariness & Venkatesh and Davis (2000) \\
\hline 186 & Job Relevance & Venkatesh and Davis (2000), Gillespie, Kim and Pandel (2007) \\
\hline 187 & $\begin{array}{c}\text { Degree of } \\
\text { Innovativeness }\end{array}$ & Schmidt and Porteus (2000) \\
\hline 188 & $\begin{array}{l}\text { Openness to } \\
\text { Innovation }\end{array}$ & Caselli and Coleman (2001) \\
\hline 189 & $\begin{array}{l}\text { General Economic } \\
\text { Conditions }\end{array}$ & Caselli and Coleman (2001) \\
\hline 190 & Success Stories & Strang and Macy (2001) \\
\hline
\end{tabular}


Constructing an Innovation Adoption Conceptual Lens/Preliminary Frame Work for Further Testing in Upstream Oil and Gas

\begin{tabular}{|c|c|c|}
\hline S No & Variables/Factors & Author(s) \\
\hline 191 & Own Experiences & Strang and Macy (2001) \\
\hline 192 & Trust & $\begin{array}{c}\text { Ruyters, Wetzel and Kleijnen (2001), Pavlou (2003), Carter and } \\
\text { Weerakkody (2008), Keller and Suzaki (1988), Casalo, Flavian and } \\
\text { Guinaliv (2012) }\end{array}$ \\
\hline 193 & $\begin{array}{l}\text { Environmental } \\
\text { Benefits }\end{array}$ & Silva, Lira and Pereira (2001) \\
\hline 194 & Higher Resale Price & Luque (2002) \\
\hline 195 & Status Levels & Tellis (2002) \\
\hline 196 & End User Involvement & $\begin{array}{l}\text { Perez, Popadiuk and Cesar (2017), Lynch (2002), Assael (1998), } \\
\text { Statnikova (2005) }\end{array}$ \\
\hline 197 & Internal Marketing & Frambach and Schillewaert (2002) \\
\hline 198 & Peer Usage & Frambach and Schillewaert (2002) \\
\hline 199 & Hedonic Motivation & $\begin{array}{l}\text { Boonsiritomachai and Pitchayadejanant (2017), Venkatesh and Morris } \\
\text { (2003), Lowry and Fienen (2013) }\end{array}$ \\
\hline 200 & Profitability & Arnholt and Balte (2003) \\
\hline 201 & $\begin{array}{l}\text { Speed of } \\
\text { Organizational } \\
\text { Changes }\end{array}$ & $\begin{array}{l}\text { Godinho and Fagerberg (2003), Bredillet, Yatim and Ruiz (2010), Norris } \\
\text { and Soloway (2011) }\end{array}$ \\
\hline 202 & Age & $\begin{array}{l}\text { Pignatti, Carli and Canavari (2015), Watcharaanantapong, Lambert and } \\
\text { Roberts (2014), Gelb and Voet (2009), D'Antoni, Mishra and Joo (2012) }\end{array}$ \\
\hline 203 & Beliefs & Black and Gregersen (2003) \\
\hline 204 & Organizational Climate & Statnikova $(2005)$ \\
\hline 205 & Job Characteristics & Statnikova (2005) \\
\hline 206 & $\begin{array}{l}\text { Work group } \\
\text { Characteristics }\end{array}$ & Statnikova (2005) \\
\hline 207 & $\begin{array}{l}\text { Management } \\
\text { Commitment }\end{array}$ & Statnikova (2005), Talukder, Harris and Mapunda (2012) \\
\hline 208 & Time Budget & Kwan and Min (2008), Paudel, Mishra and Segarra (2011) \\
\hline 209 & $\begin{array}{l}\text { Environmental } \\
\text { Benefits }\end{array}$ & Fraj and Matinez (2006), Zhang, Yu and Spil (2007) \\
\hline 210 & Personal Values & Fraj and Matinez (2006) \\
\hline 211 & Product Reviews & Clemon, Gao and Hitt (2006) \\
\hline 212 & Switching Cost & Collan (2007) \\
\hline 213 & Quality of Results & Harvey (2009) \\
\hline 214 & Quality of Service & Harvey (2009) \\
\hline 215 & Referrals & Harvey (2009) \\
\hline 216 & $\begin{array}{l}\text { Social Ties in } \\
\text { Organization }\end{array}$ & $\begin{array}{c}\text { Sykes, Venkatesh and Gosain (2009), Oster and Thorton (2010), } \\
\text { Talukder, Harris and Mapunda (2012) }\end{array}$ \\
\hline 217 & $\begin{array}{l}\text { Proper Technology } \\
\text { assessment }\end{array}$ & Norris and Soloway (2011) \\
\hline 218 & Cost Savings & D'Antoni, Mishra and Joo (2012) \\
\hline 219 & Security & $\begin{array}{l}\text { Boonsiritomachai and Pitchayadejanant (2017), Porter and Donthu } \\
\text { (2006) }\end{array}$ \\
\hline 220 & Discomfort & Porter and Donthu (2006) \\
\hline 221 & Optimism & Porter and Donthu (2006) \\
\hline 222 & Curiosity & Lowry and Fienen (2013) \\
\hline 223 & Familiarity & Pierpaolia, Carli and Pinattia (2013), \\
\hline
\end{tabular}




\begin{tabular}{|c|c|c|}
\hline S No & Variables/Factors & Author(s) \\
\hline 224 & Information Exposure & Hodas and Lerman (2014) \\
\hline 225 & Licensing & Kekana, Aigbavboa and Thwala (2014) \\
\hline 226 & Total acceptance & Aizstrauta, Ginters and Eroles (2015) \\
\hline 227 & Decision Type & Perez, Popadiuk and Cesar (2017) \\
\hline
\end{tabular}

Figure 3 Variables extracted from transcript

\subsection{DEFINIG CODES AND AXIAL CODING}

Open Codes are defined and axial coding is done to combine these Open codes to various Categories of codes (Strauss and Corbin, 1990).

Hype Cycle is the graphical representation of maturity, application and acceptance of emerging technologies. Hype cycles also overestimates the benefits of emerging technologies in the short run and underestimates the advantages in the long term. In fact, these inflated expectations lead to premature abandonment of innovative technologies without waiting for the long term benefits. Each Hype cycle goes through five phases (1) Technology Trigger: This is the phase where the news about the innovative technologies appears for the first time in the media (2) Peak of Inflated Expectations: The success stories about the innovation spread throughout the market and exaggerate the expectations about the innovation (3) Trough of Disillusionment: The technology will not be able meet the inflated expectations and end users get disappointed with the innovation (4) Slope of Enlightenment: The inflated expectations about the technology becomes realistic in this stage and the innovator learns his mistakes and make corrective actions to match the realistic expectations. The end user understands the advantages of the innovation (5) Plateau of Productivity: This is the stage where adoption really takes off in the market. The Researcher includes Hype cycle as a variable in the conceptual lens to study its impact on adoption. Optimism about the innovation creates inflated expectations. Fashion represents a "Particular manner" in which something is done or performed. Fashion embodies a particular style of doing things. Seasonality refers to "Repeating short term cycle in the series". The demand for a particular product will keep on repeating after (equal) time intervals. The Researcher assumes that the Fashion and the Seasonality influence the Hype cycles (Nechully, Pokhriyal and Eappen, 2018a).

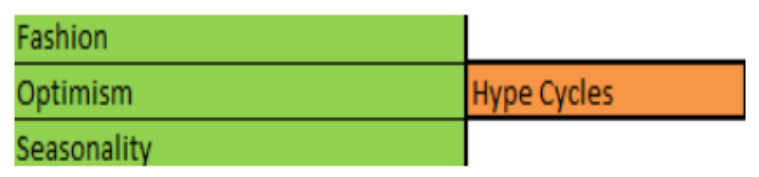

Figure 4 Hype Cycles

Resistance to change or in other words Fear of change is caused due to many reasons. Most important of all is the confidence to master and use the innovation. Perceived Behavioral Control and Self efficacy refers to the same concept - one's own confidence to perform a behavior successfully in a particular setting. Uncertainty about the performance of the innovation also contributes to the fear of change. This uncertainty is also the risk of embracing the innovation. There are also instances of reluctance to change due to satisfaction with the existing technology. Comfortableness with a particular technology encourages the end user to continue with the same technology despite of the benefits of the innovation. Inertia and Resistance to change refers to the same concept of propensity to continue with the existing technology (Nechully, Pokhriyal and Eappen, 2018c). 
Constructing an Innovation Adoption Conceptual Lens/Preliminary Frame Work for Further Testing in Upstream Oil and Gas

\begin{tabular}{|c|c|}
\hline Inertia & \\
\hline Uncertainity & \\
\hline Perceived Behavioral Control & \\
\hline Self Efficacy & Resistance to Change \\
\hline Risk & \\
\hline Satisfaction with Old Practises & \\
\hline
\end{tabular}

Figure 5 Resistances to Change

The relevant information about the innovation affects the adoption of innovation. In today's scenario with the advent of internet and other social networking sites, the prospect is often overloaded with information and often gets confused. So, it is important that the relevant information about the innovation be imparted to the prospects, the relevant information which caters to their specific requirements. There are many sources of information like Advertisements, Word of mouth, Product reviews in Social media, Internal marketing, Feedback about the usage, Referrals, Social ties in organizations, Personal Networks etc. Opinion leaders - people having in-depth knowledge about a particular technology/product in an organization are often consulted for relevant information regarding innovation. The media selected for communicating information should not distort or omit information imparted by the innovator. Repeated exposure to information embeds the information in the minds of prospects (Nechully, Pokhriyal and Eappen, 2018a).

\begin{tabular}{|l|}
\hline Feedback \\
\hline Personal Network \\
\hline Mass Communication/Media \\
\hline Available Knowledge \\
\hline Word of mouth \\
\hline Advertisement \\
\hline Social Media \\
\hline Opinions \\
\hline Direct Email \\
\hline Publicity \\
\hline Continous monitoring of Output \\
\hline Success Stories \\
\hline Media Charactertics \\
\hline Internal Marketing \\
\hline Peer Usage \\
\hline Product Reviews \\
\hline Referrals \\
\hline Social Ties in Organization \\
\hline Information Exposure \\
\hline Opinion Leaders \\
\hline
\end{tabular}

Figure 6 Information

Aftersales support refers to the services provided by the company after the delivery and or installation of the innovation. The quality of aftersales services determines the continued usage or abandonment of the innovation. Training on the product usage is considered as one of the important aftersales services. Aftersales support enhances the customer satisfaction. It is an 
important factor affecting the repeat business from the same users in the market (Nechully, Pokhriyal and Eappen, 2018c).

\begin{tabular}{|l|l|}
\hline Aftersales Service & \\
\hline Training & Aftersales Support \\
\hline Quality of Service & \\
\hline
\end{tabular}

Figure 7 After Sales Support

The purchasing patterns of an organization helps to understand what an organization buys and what it will not. History and Frequency of past purchases, Familiarity and the Organizational Habits affect the Purchasing patterns of an organization (Nechully, Pokhriyal and Eappen, 2018b).

\begin{tabular}{l|l} 
History of Past purchases & \\
\hline Frequency of Past Behaviour & \\
\hline Familiarity & Purchasing Patterns \\
\hline Habit &
\end{tabular}

Figure 8 Purchasing Patterns

Efforts required from the part of employees to learn and use the innovation affects the adoption decisions. The complexity or sophistication of the innovation enhances the perception of effort required from the end user to use the innovation (Nechully, Pokhriyal and Eappen, 2018a).

\begin{tabular}{l|l} 
Ease of Use & \\
\hline Ease to learn & Efforts \\
\hline Complexity &
\end{tabular}

Figure 9 Efforts

The customer satisfaction from the previous innovations of the innovator - whose product is under discussion, affects the adoption decisions. Dissonance is created when there is mismatch between Beliefs and Evaluations of the outcome and these dissonances creates dissatisfaction and lose of trust on the brand. "Actual" should be equal to or above the "Expected" to create satisfaction and subsequently trust on the brand. End User's experiences - pleasant and pleasurable experiences enhance satisfaction and trust. Timely production and delivery of the ordered item also enhances satisfaction and trust (Nechully, Pokhriyal and Eappen, 2018b).

\begin{tabular}{l|l} 
Beliefs of outcome & \multirow{3}{*}{ Evalaution of outcome } \\
\hline User Experience & \\
\hline User Satisfaction & \\
\hline Pleasurable Expereince & \\
\hline Perceived Fun & \\
\hline Own Expereinces & \\
\hline Production Timeliness & \\
\hline Trust & \\
\hline Hedonic Motivation &
\end{tabular}

Figure 10 User Satisfactions and Trust 
Absorptive capacity refers to a firm's ability to acquire relevant information and to exploit or use it to its advantage. Individual or CEO innovativeness or curiosity or openness of an organization to innovative ideas enhances the absorptive capacity. The organization should also be willing to make use of the newly acquired information. Research \& Development enhances the knowledge base of the organization and enhances the absorptive capacity. Fierce Competition in the market forces companies to enhance its ability to search and use relevant information. Market structure also impacts innovation adoption. Especially when it is a monopoly market, organizations have no incentives to innovate (Nechully, Pokhriyal and Eappen, 2018c).

\begin{tabular}{l|l} 
CEO Innovativeness & \multirow{2}{*}{ Individual Innovativeness } \\
\cline { 1 - 1 } Market Structure & \\
\hline Market Competition & Absorptive capacity \\
\hline R\&D & \\
\cline { 1 - 1 } Organizational Openess & \\
\cline { 1 - 1 } Interorganizational Dependence & \\
\hline Willingness &
\end{tabular}

Figure 11 Absorptive Capacity

Affordability of an innovation determines whether an organization can procure an innovation or not. Affordability depends on the Cost of innovation and Budget available to purchase the innovation. The budgets should be at least equal to the market price of innovation. Affordability is also influenced by the Revenues generated by the companies. Companies with huge profits will not confront shortage of funds for adopting innovations. The adoption of an innovation requires modification of existing procedures, investing on infrastructure for innovation and training employees on the innovation usage. These activities incur cost called Cost of adoption. In case of disruptive or radical innovations, organizations might not have the necessary skilled man power available inside the organization to handle it. So the necessary manpower is to be recruited from the market which incurs Cost of Manpower to operate Innovation. Prevailing wage rates refers to the Manpower cost. Switching cost can also become a cost of adoption if a company is replacing an existing technology with an innovation. Switching cost and Cost of adoption can be one and the same unless and until it is a disruptive innovation. Switching cost is defined as the cost incurred to change the supplier. Time and Effort invested to identify and master the alternative(s), Exit Fees, Financial Risk and Installation and Startup cost are the normal switching costs. In fact, the demarcation between cost of adoption and switching cost is a very thin line (Nechully, Pokhriyal and Eappen, 2018a).

\begin{tabular}{l|l} 
Switching Cost & \multirow{2}{|}{} \\
\cline { 1 - 1 } Affordability & \\
\hline Income & Affordability \\
\hline Prevailaing Wage Rates & \\
\cline { 1 - 1 } Purchasing Power & \\
\cline { 1 - 1 } Budget allocation &
\end{tabular}

Figure 12 Affordability

Perceived Usefulness refers to the belief on the ability of a particular system to improve the performance of an organization. Benefits refer to "Something intended to help". So the 
Researcher clubs both Perceived Usefulness and Benefits as Perceived Usefulness and Benefits. A Benefit that can be quantified in terms of money generated or saved is called Economic Benefits. Cost Savings, Time budgets, Better pay, Enhanced Job Performance and Economies of scale can be considered as Economic Benefits. Economies of Scale lead to cost saving. The cost per unit of output decreases with increasing production levels. The expectations about the useful features of the innovation enhance the perceived usefulness. Security, Safety and Convenience to use the innovation enhances the Perceived usefulness. Relative advantages of the innovation and Exciting benefits that an innovation can deliver enhance the Perceived usefulness. Exciting benefits delights customers, subsequently enhances usefulness drastically. Nowadays all organizations are exploring ways to enhance its environmental commitments. So innovations delivering Environmental benefits increase the usefulness of innovations (Nechully, Pokhriyal and Eappen, 2018c).

\begin{tabular}{|c|c|}
\hline Cost Savings & \\
\hline Profitability & \\
\hline Environmental Benefits & \\
\hline Long term consquences & \\
\hline Security & \\
\hline ROI & \\
\hline Convenience & \\
\hline Perceived Innovation Characterisitcs & \\
\hline Safety & \\
\hline Time Budget & Percieved Usefulness and Benefits \\
\hline Environmental Benefits & \\
\hline Market Potential & \\
\hline Better Pay & \\
\hline Enhaced Job Performance & \\
\hline Exiciting Benefits & \\
\hline Relative Advantage & \\
\hline Economies of Scale & \\
\hline Economic Benefits & \\
\hline
\end{tabular}

Figure 13 Perceived Usefulness

Organizational and Technical infrastructure available to support innovation usage are called facilitating conditions. One more dimension of Government support also has to be added to the above definition of facilitating conditions. In case of Sophisticated Technologies, Government support also plays a vital role in adoption. Innovator support in terms of Flexible payment schemes and Credit facility helps cash deficient organizations to adopt innovations. Innovator support is also required during Installation and Commissioning stage. In case of sophisticated technologies, in most cases, a sale is considered as completed if the technology is successfully installed and commissioned at end user premises. Or the end users are to be trained on the installation and commissioning. Innovator support cultivates a healthy relationship between innovator and the end user which significantly impacts adoption decisions. A healthy relationship makes the Licensing procedures easy and less time consuming. Technology stewards are people who know very well the requirements of a particular market and are well versed with the innovative technologies best suited for that market. Technology stewards take initiatives to select and use the innovative technologies in an organization. Managerial skills are required to identity the benefits of innovations and to make necessary changes required in organization for innovation adoption. Management Support and Commitment is required at each stage of adoption. Proper Technology assessment/Knowledge of Technology/Degree of innovativeness helps an organization to anticipate the necessary infrastructure requirement for 
innovation adoption. Degree of Innovativeness refers to whether an innovation is incremental/disruptive or radical. General Economic conditions like recession affects the budget allocations in the company and government funds. An efficient and effective Organizational leadership is required to coordinate all activities related to innovation adoption - without which the whole process goes astray. The Innovation opportunity in an organization should be aligned with the Organizational priorities. Otherwise the innovation opportunity gets discarded. Innovation policy refers to a general plan or method of action devised by an organization to adopt innovation. Organizational strategies refer to how these policies can be implemented with respect to specific innovations (Nechully, Pokhriyal and Eappen, 2018c).

\begin{tabular}{l|l|}
\hline Knowledge of Technology & \multirow{3}{*}{ Complimentary Infrastructure } \\
\hline Government Support & \\
\hline Managerial Skills & \\
\hline Relationship & \\
\hline Degree of Innovativeness & \\
\hline General Economic Conditions & \\
\hline Proper Technology assessment & \\
\hline Credit Availabilty & \\
\hline Innovator Support & \\
\hline Licensing & \\
\hline Technology Steward & \\
\hline Innovation policy & \\
\hline Leadership & \\
\hline Management Support & \\
\hline Organizational Strategies & \\
\hline Organizational Priorities & \\
\hline Management Commitment &
\end{tabular}

Figure 14 Facilitating Conditions

Repurchase refers to repetitive buying by the end users, Substitution refers to replacement of an existing technology or obsolete technology by an innovation, new purchase refers to adoption of an innovation without replacement - for an entirely new innovation opportunity. In this study, the researcher merges these three concepts as these three concepts are closely related. Technological advances and speed of organizational changes necessitates Replacement/Substitution/New Purchase. Reversibility refers to opportunities/favorable conditions to switch back to the old ways of doing things. Availability of alternatives in the market encourages the organizations to constantly monitor the appropriateness of the existing technology in the changing contexts. As the number of alternatives and reversibility opportunities increases, the chances of organization to make Replacement/Substitution/New Purchase decisions increases. Last ditch efforts for survival from the innovator at the decline stage by modifying the features or by reinvention - finding new applications for the existing products results in Replacement/Substitution/New Purchase decisions. Sometimes these ReInvention initiatives come from the end users by modification or introduction of new processes or reorganization of the existing processes in the organization. Marketing strategies/efforts of the innovator also affects adoption decisions. Brand loyalty explains why the organizations purchase innovative technologies from some innovators only. Brand loyalty in fact enhances the switching barrier. Intergenerational competitions of technologies also affect the Substitution decisions - which is very evident in Computer and Mobile Phone industries. Higher Resale 
price of technology on the verge of obsolescence also affects the Replacement/Substitution/New Purchase decisions (Nechully, Pokhriyal and Eappen, 2018a).

\begin{tabular}{|c|c|}
\hline Higher Resale Price & \\
\hline Last ditch effort & \\
\hline Substitution & \\
\hline Intergenerational Competitions & \\
\hline Objectives & \\
\hline Reversibility & \\
\hline Technological advances & Re-Purchase/Substitution/New Purchase \\
\hline Speed of Organizational Changes & \\
\hline Alternatives & \\
\hline Brand Loyalty & \\
\hline Re-Organizing & \\
\hline Marketing Strategies & \\
\hline Re-Invention & \\
\hline
\end{tabular}

Figure 15 Re-Purchase/Substitution/New Purchase

The resources of an organization play an important role in adoption decisions. Skilled man power should be available in the organization to utilize the adopted innovation. Employee education levels and experience contributes a lot to acquiring the necessary skill sets. Some of the industries require the innovator to have a local presence and in these cases the distribution channels represent the innovator. All efforts of the innovator will be channeled through the distributor and the distributor plays a significant role to convince the end users. More over the distributor will be thorough with the local conditions or requirements. A good distributor is an important resource of an innovator (Nechully, Pokhriyal and Eappen, 2018b).

\begin{tabular}{l|l} 
User Skills & \\
\hline High Education Levels & Resources \\
\hline Distribution Channel &
\end{tabular}

Figure 16 Resources

An innovation should first prove its Scientific Credibility without which the organizations will be very reluctant to absorb innovation. System reliability refers to consistency of results from the innovation over a period of time. Quality of an innovation refers to the reliable bench mark performance an innovation can deliver over a period of time. System reliability and subsequently quality of results/performance affects the scientific credibility. Product features relevant to the organization and visibility of the results enhances the scientific credibility. Demonstration of the instrument with a prototype at the site and the subsequent results enhance the scientific credibility of the innovation. Prototypes are also given for Field trial to organizations - which also enhance the scientific credibility (Nechully, Pokhriyal and Eappen, 2018b).

\begin{tabular}{l|l} 
System Relaibility & \multirow{2}{*}{ Quality of Results } \\
\cline { 1 - 1 } Visibility & \\
\hline Product Features & \\
\hline Prototype & \\
\hline Demonstration &
\end{tabular}

Figure 17 Scientific Credibility 
Organization adopts Innovation for want of Statutory or Group compliances. Reference group is a group which is considered as a standard for comparison and the behavior of the reference group is imitated for want of compliance. The organization or individual aspires to relate to this group by imitating their behavior. Reference group provides the comparison bench marks. At times statutory regulations make an innovation adoption compulsory for survival in a particular market. Imitation is also done to preserve Membership in Industrial Network compliances. This concept is also called Legitimization. Legitimization is the process of making the organization acceptable to a particular Network or industry by Imitation. Social approval pressure also affects adoption decisions. Social approvals enhance the image or reputation of the firm. The intensity and speed of compliances are also influenced by the relevance of the compliances to the job. Compliances with Internationally accepted Industrial standards cannot be dispensed with. The presence of a central decision maker dispels all confusions regarding the compliances and make sure that all organizations with in a particular industry coming under the jurisdiction of central decision maker adheres to the stipulated compliances. Status levels are same as that of reputation. Geographical proximity to the network members, trading power of other network members and Number of network members already using innovation enhances the speed and intensity of compliances. Higher number of adopters'/Market share enhances the value of innovation - this concept is called network externality. Compliance due to Social and Industry pressures is called Isomorphism (Nechully, Pokhriyal and Eappen, 2018c).

\begin{tabular}{|c|c|}
\hline Reference Group & \\
\hline Conformity & \\
\hline Government Regulation & \\
\hline Status Levels & \\
\hline Job Relevance & \\
\hline Isomorphism & \\
\hline Number of Adopters & \\
\hline Network Externality & \\
\hline Market Share & \\
\hline Geographical Proximity & \\
\hline Social Pressure & \\
\hline Image enhancement & Statutory and Group Pressure Complainces \\
\hline Central Decision Maker & \\
\hline Herd Behaviour & \\
\hline Imitation & \\
\hline Trading Partner Power & \\
\hline Legitamization & \\
\hline Network Membership & \\
\hline Social Approval/Influence & \\
\hline Complainces & \\
\hline Standards & \\
\hline Statutory Complaince & \\
\hline Reputation of the Firm & \\
\hline
\end{tabular}

Figure 18 Statutory and Group Pressure Compliance

The level of customization an innovation can offer to an organization enhances the compatibility with its existing systems and procedures. Organizational discomfort aggravates the need for customization and subsequent compatibility. The innovation should have the flexibility for Industry/Organization/Work settings specific adaptability (Nechully, Pokhriyal and Eappen, 2018a). 


\begin{tabular}{l|l}
\hline Compatability & \multicolumn{1}{|l}{} \\
\hline Fit to Work Settings & Customization and Compatability \\
\hline Discomfort & \\
\hline Local Adaptations &
\end{tabular}

Figure 19 Customization and Compatibility

Market potential of an innovation viewed from an adopter perspective is nothing but perceived usefulness and benefits but from an innovator point of view is the market share the innovation can achieve with in a specific time period. Here Market potential was grouped as a variable affecting Decision types. The Researcher removes it from there and add it to Perceived usefulness and benefits. Objectives of the organization were wrongly grouped as a variable influencing decision type. In fact, the Objectives of the organization influence Replacement/Substitution/New Purchase decisions (Nechully, Pokhriyal and Eappen, 2018b). There are four different styles of decision making (1) Autocratic - Decisions ae made by the manager without consulting subordinates (2) Consultative - Manager seeks opinions from his colleagues but make the final decisions by himself (3) Team - The decision is made on the basis on consensus - even if you are personally against it you support the majority decision (4) Delegating - Subordinates are empowered to make appropriate decisions. The end user involvement is very important in decision making as it gives a sense of responsibility during implementation and utilization stages. The end user involvement is further affected by motivation levels, age and voluntariness. Motivation levels enhance the voluntariness to come forward and to give valuable inputs to the organization. Various studies confirm that Young employees actively take part in decision making process. The communication channels facilitate the smooth flow of suggestions for decision making and facilitate the communication of decisions to various levels in the organization. Organizational structure provides a representation of the shape of the organization. Organizational structure determines how a decision is made in an organization. For a Centralized Structure - the decision is made at the top and subordinates are made to obey. In a decentralized system - the decisions are made at various levels and are of participatory in nature. To accelerate the decision making process, nowadays organizations embrace a flat structure where bureaucratic levels are lesser in number and employees are given more autonomy to make decisions. As the size of the company becomes bigger, the time taken to make decisions also increases (Nechully, Pokhriyal and Eappen, 2018a).

\begin{tabular}{|l|l|}
\hline Organization Structure & \\
\hline Age & \\
\hline Communication Channels & \\
\hline End User Involvement & Decision Styles \\
\hline Motivation & \\
\hline Voluntariness & \\
\cline { 1 - 1 } Company Size &
\end{tabular}

Figure 20 Decision Styles

Organizational Customs dictate how a particular task is carried out in the organizational context. Organizational customs explain how the people should behave in the organization. To make it simple - Organizational customs defines how things are done in the organization. Each department or team with in an organization will have their own way of doing things Team/Department Specific customs. Organizational routines are interaction patterns (between 
employees) relevant for the coordination of organizational activities. Organizational routines help to save time and efforts in the decision making process. Organizational routines impact Organizational Customs. Organizational routines are interaction patterns developed over time for controlling and coordinating organizational activities. Routines are the standardized procedures or practices of an organization. Organizational norms refer to the set of rules governing the behavior of employees in an organization. It is in fact the accepted work place behaviors in an organization. Normative beliefs are perceptions about the acceptability about the behaviors either by the society or people relevant or close to the individual performing the behavior. Normative beliefs of the employees influence the compliance with Organizational customs. Subjective norms are pressures to perform or not perform a (set) of behavior(s). Values are principles or qualities or standards that are held in high regard by the organization or individuals. Values guide the operations in a particular environment. The personal traits of the employees also influence the compliance with organizational customs (Nechully, Pokhriyal and Eappen, 2018c).

\begin{tabular}{l|l}
\hline Norms & \\
\hline Personal Influences & \\
\hline Routines & \\
\hline Normative beliefs & \\
\cline { 1 - 1 } Subjective Norms &
\end{tabular}

Figure 21 Organizational Customs

Organizational climate is the general feeling an employee has or the atmosphere employees experience in an organization on a day to day basis. Working environment significantly impacts the organizational climate. A conducive work environment ignites creativity in the minds of employees. Well defined Job roles, Delegation of decision making powers, stability of job and work group characteristics contributes to Organizational climate (Nechully, Pokhriyal and Eappen, 2018a).

\begin{tabular}{l|l}
\hline Cross functional teams & \\
\cline { 1 - 1 } Job Charactertics & \\
\hline Work group charactertics & \\
\hline Authority & \\
\hline Job Tenure & \\
\hline Job Roles &
\end{tabular}

Figure 22 Organizational Climate

\subsection{SELECTIVE CODING}

Selective coding is the process of connecting the categories of codes to a core category or core concept (Strauss and Corbin, 1990).

Organizational culture refers to a set of interconnected assumptions which have helped organizations to tackle internal and external challenges in the past and which are perceived to be useful to tackle current and future challenges (Schien, 1995). Organizational culture evolves over a period of time, out of experiences and learning. Both Organizational customs and Organizational climate contributes to Organizational culture. Theoretically Organizational culture and Organizational Climate influences each other. Organizational culture provides a holistic over view of the operations of the organization. Accumulation of the feelings about the actions complying with the organizational customs which have produced desired results 
contributes to Organizational culture. An organizational climate can be temporarily created or modified by the company management where as an evolution of organizational culture is a long term process. Managers should focus on "Cultural Shift" rather than "Climate shift" for enhancing the performance of organizations (Nechully, Pokhriyal and Eappen, 2018a).

\begin{tabular}{l|l|}
\hline Organizational Climate & Organizational Culture \\
\hline Organizational Customs & \multicolumn{1}{|l}{} \\
\hline
\end{tabular}

Figure 23 Organizational Culture

Organizational Innovativeness is defined as the ability of an organization to search and find solutions for innovation opportunities either within or outside the organization. It can also be defined as the inherent capability and tendency of an organization to experiment with and procure the innovative technologies/services either developed by the R\&D or by an external innovator. Purchasing patterns give us an indication of organizational innovativeness. Ability to learn about the new technologies - Absorptive capacity enhances the organizational innovativeness. Lack of proper facilitating conditions in the organization retards Innovativeness. Relevant Information about the various innovations available in the market enhances Organizational innovativeness. The availability of sufficient resources encourages organizations to search for innovations (Nechully, Pokhriyal and Eappen, 2018c).

\begin{tabular}{l|l}
\hline Absorptive Capacity & \multicolumn{1}{|l}{} \\
\hline Purchasing Patterns & \\
\hline Facilitating Conditions & Organizational Innovativeness \\
\hline Resources & \\
\hline Information &
\end{tabular}

Figure 24 Organizational Innovativeness

The Intention to use signifies the "Ambition" or "Aspiration" to use an innovation. Inflated expectations influence the first time use. End User involvement in the decision making process gives them a sense of responsibility to put the innovation into use especially when the decision makes styles are Team, Delegating or Consultative. At times, the innovation is used due to compliance pressures. The flexibility of an innovation to get customized and compatible with the existing work settings enhances the propensity to utilize an innovation. Satisfaction received in the past from the products of the innovator enhances trust and ultimately intensify the aspiration to use a particular innovation from the same innovator. The record of aftersales service also affects the Intention to use. Fear of Technology or satisfaction with the old practices diminishes the ambitions to use an innovation (Nechully, Pokhriyal and Eappen, 2018b).

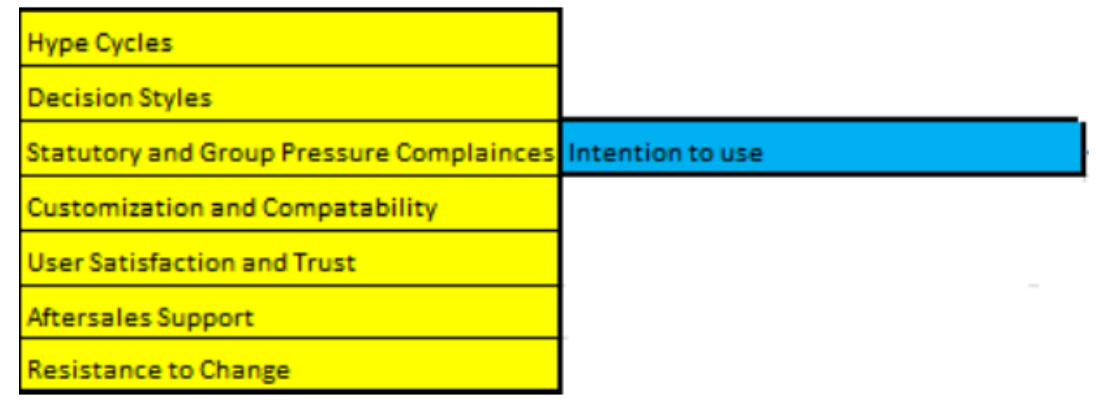

Figure 25 Intentions to Use

Attitudes define the feelings for a particular product/person or some other things. Scientific credibility of an innovation develops a favorable attitude towards innovation. Affordability of 
the innovation also enhances the favorable attitude. A sense of "Affordability" encourages the end users to explore more about the innovation. Usefulness and Effort required impacts the attitude. End users have a natural inclination towards innovation that is easy to learn and use. Perceived Benefits cultivate a favorable attitude towards innovation (Nechully, Pokhriyal and Eappen, 2018a).

\begin{tabular}{l|l|}
\hline Effort (Perceive ease to learn and use) & \\
\hline Percieved Usefulness and Benefits & Attitude \\
\hline Scientific Credibility & \\
\hline Affordability &
\end{tabular}

Figure 26 Attitude

Organizational Readiness refers to the collective ability and commitment of the employees to adopt innovations in an organization. To enhance organizational readiness, the organization should have an overall organizational environment (Organizational culture) which encourages innovation and the ability to procure the right innovation for the organization (Organizational Innovativeness). Organizational Innovativeness and Organizational culture impact Organizational readiness (Nechully, Pokhriyal and Eappen, 2018a).

Finding an Innovation opportunity in an organization requires commitment and ability from the part of organization and a favorable attitude towards opportunities for betterment within an organization. Innovation Opportunity is impacted by Attitude and Organizational Readiness. Selection of an appropriate technology for the innovation opportunity is also impacted by the same variables - Attitude and Organizational Readiness. These two stages constitute PreAdoption stage (Nechully, Pokhriyal and Eappen, 2018b).

Organizational ability and Commitment and Inclination towards a particular Innovation affects the Contract finalization stage. Implementation of an innovation depends on the Organizational readiness. Utilization of an innovation depends on the intention of employees to use it, their feelings towards the innovation and organizational readiness. Contract finalization, Implementation and Utilization constitutes adoption stage (Nechully, Pokhriyal and Eappen, 2018a).

Future Technology usage depends on the intention of the employees and Repurchase/Substitution/New Purchase decisions. Future Technology usage constitutes Post adoption phase.

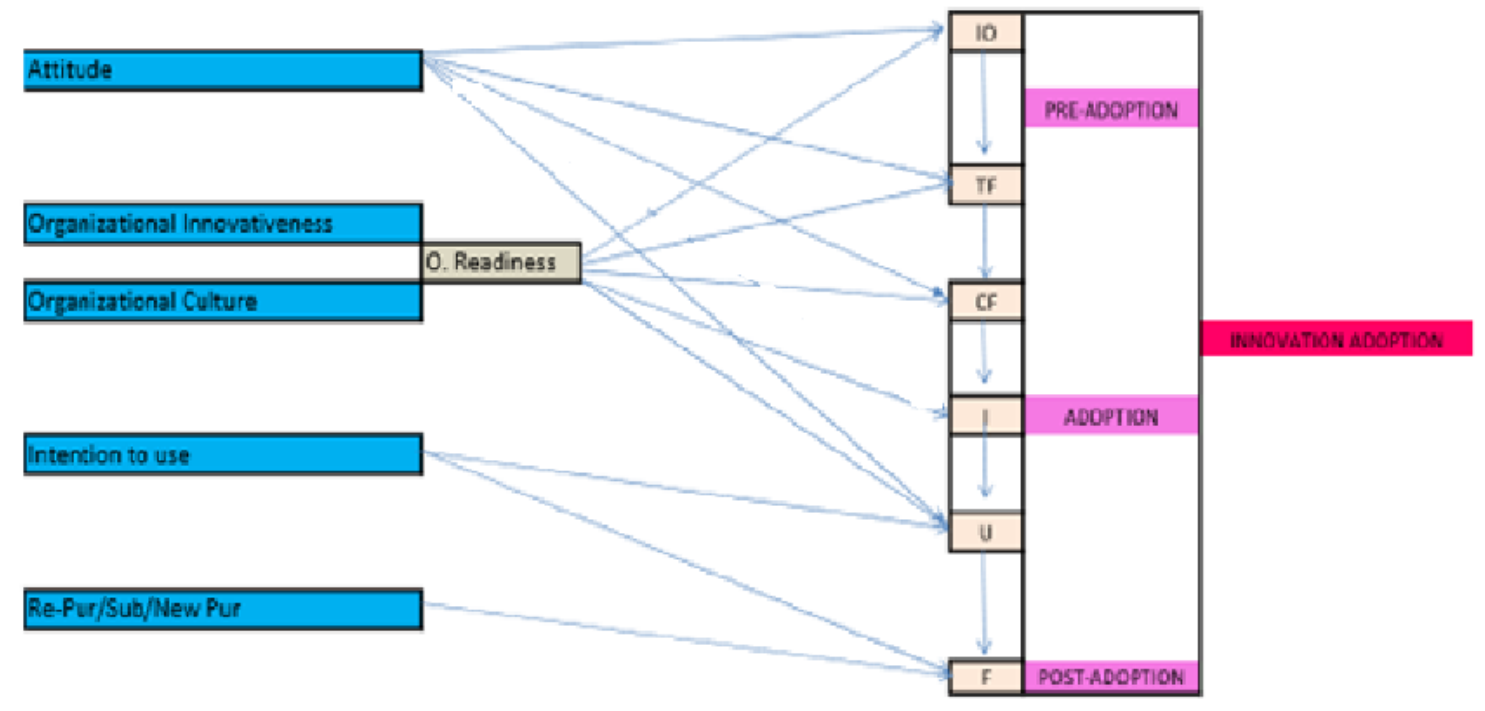

Figure 27 Conceptual Lens 
In the above Figure 27, IO: Innovation Opportunity, TF: Technology Finalization, CF: Contract Finalization, I: Implementation, U: Utilization, F: Future Technology Usage

\section{CONCLUSION}

Now that the Conceptual Lens/Preliminary Frame work is made, the direction or the focus required for the research is crystal clear. The Conceptual lens provides the basis for drafting the questions to be asked to the respondents. The Conceptual lens can be treated as the starting point for qualitative data analysis. The variables defined in the process of constructing conceptual lens will be used as "Pre-Defined Codes" for further qualitative analysis.

\section{REFERENCES}

[1] Anderson, L. W. and Krathwohl, D. R. A taxonomy for learning, teaching, and assessing: A revision of Bloom's taxonomy of educational objectives. New York: Longman, 2001.

[2] Cooper, R. B. and Zmud, R. W., Information Technology Implementation Research: A Technological Diffusion Approach. Management Science, 36(2), 1990 pp. 123-139

[3] Nechully, S. N., Pokhriyal, S.K. and Eappen, S. A Journey through Evolution of Theories and Models of Adoption of Innovations (Year: 1798-1980). International Journal of Mechanical Engineering and Technology, 9(10), 2018 pp. 1-36

[4] Nechully, S. N., Pokhriyal, S.K. and Eappen, S. A Journey through Evolution of Theories and Models of Adoption of Innovations (Year: 2000-2018). International Journal of Production Technology and Management, 9(2), 2018 pp. 31-73

[5] Nechully, S. N., Pokhriyal, S.K. and Eappen, S. A Journey through Evolution of Theories and Models of Adoption of Innovations (Year: 1981-1999). Journal of Management, 5(5), 2018 pp. 97-143

[6] Schien, E, Organizational Culture and Leadership. San Francisco: Jossey-Bass, 1995.

[7] Strauss, A. and Corbin, J. M. Basics of Qualitative Research: Grounded Theory Procedures and Techniques. Thousand Oaks: Sage Publications, 1990. 